\title{
Economic values of Ulu Chepor Recreational Park, Perak: a travel cost approach
}

\begin{abstract}
The estimation of economic values of Ulu Chepor Recreational Park (UCRP) is needed because no study has been done so far in valuing this area. By applying the travel cost model, the travel information is then used for the estimation of the recreational values in UCRP. The recreational value of Willingness To Pay (WTP) per person derived is estimated at RM2.30 per visit. The total recreational net benefit is estimated at RM33,120 for the year 2012. This implies that the significant economic values of eco-tourism will be lost from any large scale development by degrading natural environment. On top of that, the management of UCRP could generate more income and use it for maintenance purposes. For the time being, visitors will be charged RM2 per car per entry. In fact, there is no charge for visitors that come by motorcycle. Therefore, this finding is useful for them and can be used as a basis to change the current practice for the future benefit of Ulu Chepor Recreational Park.
\end{abstract}

Keyword: Recreational values; Eco-tourism; Willingness to pay; Economic valuation 